\title{
PHYSIC NUT (Jatropha curcas L.) GROWTH AND PHYTOMASS ACCUMULATION RATE
}

\author{
CRESCIMENTO E MARCHA DE ACÚMULO DE FITOMASSA EM PINHÃO-MANSO
} (Jatropha curcas L.)

\section{Carlos Hissao KURIHARA; Hamilton KIKUTI²; Flávio Ferreira da Silva BINOTTI³; Cesar José da SILVA ${ }^{1}$}

1. Doutor, Embrapa Agropecuária Oeste, Dourados, MS, Brazil. carlos.kurihara@embrapa.br; 2. Professor, Doutor, Universidade Federal de Uberlândia - UFU, Uberlândia, MG, Brazil; 3. Professor, Doutor, Universidade Estadual de Mato Grosso do Sul - UEMS, Unidade Universitária de Cassilândia, Cassilândia, MS, Brazil.

\begin{abstract}
Jatropha plants are known to be a rustic, low-demanding crop for nutrients and water. For that reason, they have been cultivated in restoring degraded areas or as windbreak. Nevertheless, under appropriate soil and climate conditions, this crop may become an alternative for biodiesel production due to high oil content and industrial quality. Studies on the growth and the phytomass accumulation rate of shoots of perennials permit subsidize management practices of culture, such as the definition of the population and the plant arrangement; it also enables the estimation of demand and potential recycling of nutrients, which contributes to establishing the most suitable amount and time for supplying fertilizers in cover. Studies on plant growth and phytomass accumulation have been conducted for a relatively short period of time, sometimes under greenhouse conditions. This trial design was carried out in Cassilândia-MS, for 52 months, with the objective of evaluating Jatropha growth and phytomass accumulation. The experimental design was completely randomized with four replications and 15 treatments, consisting of evaluation times. Jatropha growth, mainly height, stems and crown diameter, is accentuated in the first 12 to 15 months after seedling transplanting. Crown diameter showed a new growth cycle between the $35^{\text {th }}$ and the $52^{\text {nd }}$ month, superior than observed in the initials stages of growth. Stem phytomass accumulation is relatively low until eight months after seedling transplanting, being considerably increased after this period. Intense senescence and leaf abscission is observed in drier and colder periods of the year.
\end{abstract}

KEYWORDS: Height. Stem diameter. Crown diameter. Number of branches.

\section{INTRODUCTION}

The Jatropha is a plant that belongs to the Euphorbiaceous family. It is perennial and shrubby and it has deciduous habit - it is normally about two and three meter high, but it can reach five meters high in especial conditions (ARRUDA et al., 2004). It is considered a rustic plant that grows in low natural fertility soils (ARRUDA et al., 2004; SATURNINO et al., 2005), however, in adequate nutrients availability conditions it has been showing a production potential of 4,000 g grains plant ${ }^{-1}$ from the fourth culture year on (TOMINAGA et al., 2007), when the plants from seeds get the productive age (ARRUDA et al., 2004).

The last years, works on this culture have been published in which agronomic issues are approached. Studies on the growth and progress of phytomass accumulation of perennial plants air parts are essential to supporting culture management practices such as the population definition and the plants arrangement; it also provides the estimate of the demand and the nutrients recycling potential, what contributes for the most adequate quantity and period for the fertilizers in cover supply. However, growth and dry matter in Jatropha plants evaluations have been covered in relatively short period of evaluation - in conditions of greenhouse (PACHECO et al., 2006; SILVA, 2010; MEDEIROS et al., 2013; FREIBERGER et al., 2014) or field (SMIDERLE; KROETZ, 2009; PRATES et al., 2011; ARRUDA et al., 2013; DALCHIAVON et al., 2013). It is been checked that this oilseed shows clear leaves senescence in the fall/winter period - followed by a new development cycle when the temperature and the hydric availability become favorable again (ALVES et al., 2008; SMIDERLE; KROETZ, 2009). It is also been observed that the growth rate is more intense in the vegetative development stage (CARVALHO et al., 2013), but even in this stage, the plants growth becomes more limited in conditions of lower hydric availability - and this effect is more evident for the varieties of plants height, number of branches, crown diameter and dry phytomass of air part (ALBUQUERQUE et al., 2009; SILVA, 2010; ARRUDA et al., 2013).

This work has aimed to evaluate in field the growth and the progress of the dry matter phytomass accumulation in Jatropha plants for a 52 months period, in the soil and climate conditions of 
Cassilândia-MS, under typical dystrophic Red Latosol, medium texture.

\section{MATERIAL AND METHODS}

The trial design was carried out in the Experimental Field of the State University of Mato Grosso do Sul (UEMS), University Unit of Cassilândia-MS, in typical dystrophic Red Latosol, medium texture.

The seedlings were transplanted to the field area in November $21^{\text {st }} 2008$, with two definitive leaves, $4 \times 2 \mathrm{~m}$ spaced and with a population of 1,250 plants per hectare. The planting fertilization was consisted of the application of 82, 125, 55, 101, 2, 2 and $4 \mathrm{~kg} \mathrm{ha}^{-1}$ of $\mathrm{N}, \mathrm{P}_{2} \mathrm{O}_{5}, \mathrm{~K}_{2} \mathrm{O}, \mathrm{S}, \mathrm{B}, \mathrm{Cu}$ and $\mathrm{Zn}$, respectively, by using ammonium sulfate, triple superphosphate, potassium chloride, borax, copper sulfate and zinc sulfate, as source, respectively. The application of $\mathrm{N}, \mathrm{K}$ and $\mathrm{S}$ was parceled in three times (during the seedlings planting and on the $53^{\text {rd }}$ and $90^{\text {th }}$ days) and the other nutrients were applied only into the pit. The topdressing was also done with $38 \mathrm{~kg} \mathrm{ha}^{-1}$ of $\mathrm{N}$ and $\mathrm{P}_{2} \mathrm{O}_{5}$ and $25 \mathrm{~kg} \mathrm{ha}^{-1}$ of $\mathrm{K}_{2} \mathrm{O}$ in the beginning of the second year, and $45 \mathrm{~kg} \mathrm{ha}^{-1}$ of $\mathrm{N}$ and $\mathrm{P}_{2} \mathrm{O}_{5}, 30 \mathrm{~kg} \mathrm{ha}^{-1}$ of $\mathrm{K}_{2} \mathrm{O}$ and $54 \mathrm{~kg} \mathrm{ha}^{-1}$ of $\mathrm{S}$ in the others, by using the same sources mentioned before. The fertilizer in cover was applied in two parcels - the first one during the period from October to December and the second one between January and March.

The trial design used was completely randomized with four repetitions and 15 treatments that were related to the evaluation periods $(0,90$, 146, 235, 375, 459, 593, 669, 738, 873, 1047, 1146, 1277, 1431 and 1571 days after the transplanting DAT). The first evaluation was done in Jatropha's seedlings before the transplanting; on occasion of the trial design installation allocation, the experimental unities allocation for the other sampling periods has been done. Therefore, the time (DAT) was used as a study factor.

During the period of the experiment conduction, maximum and minimum temperature and rainfall data (Figure 1) were recorded at the Automatic Weather Station located $10 \mathrm{~km}$ from the experimental area (CEMTEC/MS, 2017).

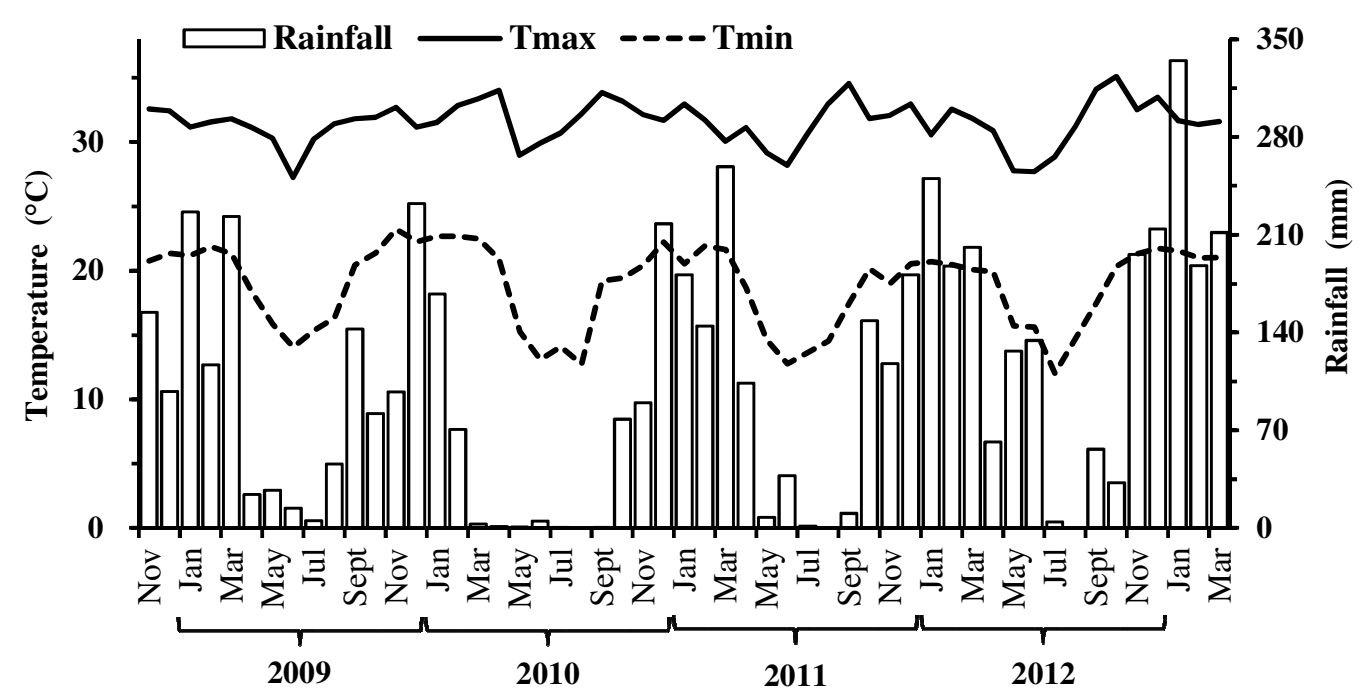

Figure 1. Maximum and minimum temperature (monthly average) and rainfall recorded in Cassilândia, MS, between November/2008 and March/2013. Source: Cemtec/MS (2017).

In every sampling period there was an evaluation of the plants height, the crown (in the perpendicular direction to the cultivation line) and the stem diameter and the number of branches. The plants height and the crown diameter were defined through the use of a graduated ruler (up to 90 DAT) and topographic ruler (from 146 DAT on), with $1 \mathrm{~cm}$ of accuracy, and the stem diameter was measured in a height around $5 \mathrm{~cm}$ over the soil level, through a digital pachymeter with $0.01 \mathrm{~mm}$ of accuracy. Then, the stem was cut nearly $5 \mathrm{~cm}$ high, and so there was the separation process of leaves, stems and branches, and finally the branches and stems cutting in pieces of 3 to $15 \mathrm{~cm}$.

The vegetal material collected in each trial unit was packaged in paper bags with the capacity for $5 \mathrm{~kg}$, and then they were put outdoor in order to get dry for nearly a 21 days period, so they were exposed to drying in forced air oven at $60{ }^{\circ} \mathrm{C}$, for nearly 120 hours, for the dry matter phytomass determination.

Face to the intense vegetative growth shown 
by the Jatropha, the option was varying the number of plants evaluated by trial unit with the intention of enabling the procedures of processing and drying of leaves, stems and branches phytomass sampled. Thus, the trial unit was constituted of twelve useful plants by repetition in the first sample (0 DAT), by randomly choosing the seedlings among the ones used in the planting process; three useful plants in the second evaluation (90 DAT), two useful plants between the third (146 DAT) and the thirteenth (1,277 DAT), and a unique useful plant in the last two measurements (1,431 and 1,571 DAT), according to Kurihara et al. (2016). The trial units constituted of three, two and one useful plant were composed by fifteen, twelve and nine plants respectively. The evaluation criterion of one lonely useful plant of Jatropha for trial unit was also used by Oliveira and Beltrão (2010) and also by Saraiva et al. (2013), during the 300 and 120 days after the seeding process, respectively.

The average values were submitted to the regression analysis through the use of the software SAEG v. 9.1 - 2007, in order to establish a better adjusted model to the analyzed variables answers related to the plants age (DAT). It was defined, among the regression models that were tested (linear, quadratic, cubic, square root and exponential), for each group of variables, the one with bigger determination coefficient, whose equation parameters estimators were significant, at least $5 \%$ of probability.

\section{RESULTS AND DISCUSSION}

A cubic model adjustment for Jatropha plants height related to the age was obtained (Figure 2 ) and substantial increases of nearly 15 months old were verified (459 DAT), except to the period from April to July 2009 (146 and 235 DAT), which was characterized with low temperature and less hydric availability (Figure 1). During the following two years, from 15 to 38 months (between 459 and 1,146 DAT) after the seedlings transplanting, the vertical growth became less intense; however, from the third evaluation year (between 1,146 and 1,571 DAT), the plants showed new growth cycle, this one was less pronounced compared to the one that was verified in the first fifteen months. In a wide bibliographic review about the Jatropha cultivation, Saturnino et al. (2005) mention that this specie can easily adapt to different climate conditions, so standing long drought periods; however the plant growth stops when the rainfall is confining. On the other hand, direct answers of Jatropha plants height increase, due to hydric availability increases in the soil, have been observed (ALBUQUERQUE et al., 2009; SIMÕES et al., 2014).

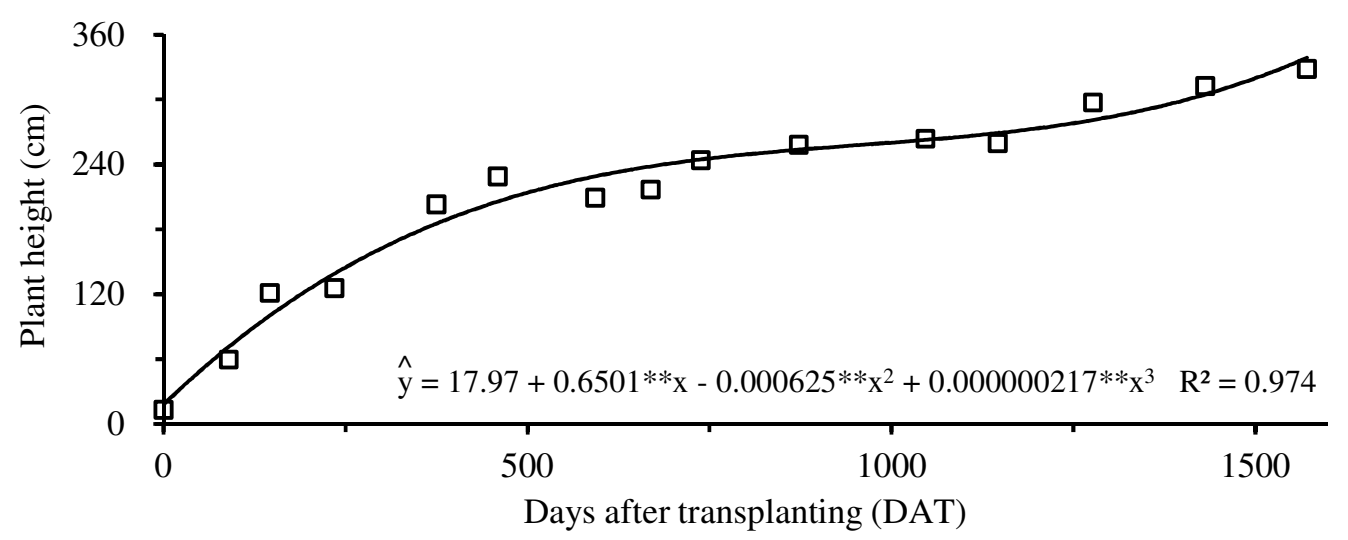

Figure 2. Jatropha plants height according to the number of days after the seedlings transplanting in typical dystrophic Red Latosol, medium texture.

The maximum height (Figure 2), $338 \mathrm{~cm}$, has been found in the $52^{\text {nd }}$ month $(1,571$ DAT), what is in consonance with the expected growth for adult plants of this specie, about two to three meters, according to Arruda et al. (2004), or from three to five meters, according to Saturnino et al. (2005). However, one must emphasize that the adult plants have to be kept with about two meters high, through annual trimmings with the objective of making easier the cultivation and plant cares and the harvest process.

Through the adjusted regression model, it was estimated that in the first growth cycle, up to 459 DAT, the plants shown $206 \mathrm{~cm}$, it means, an increase of $188 \mathrm{~cm}$ in relation to the seedlings size $(18 \mathrm{~cm})$, on the occasion of the transplanting. That results in a vertical growth rate of $0.409 \mathrm{~cm} \mathrm{day}^{-1}$. Based on the same reasoning, the height increase was calculated in the period between 459 and 1,146 
DAT $\left(0.0918 \mathrm{~cm} \mathrm{day}^{-1}\right)$ and between 1,146 and 1,571 DAT $\left(0.163 \mathrm{~cm} \mathrm{day}^{-1}\right)$, what allowed the inference that the plants growth during the first 15 months was 345 and $151 \%$ superior compared to the verified one in the two following periods, between 15 and 38 months and between 38 and 52 months, respectively. In the medium north region of the State of Mato Grosso, Dalchiavon et al. (2013) have observed, in the 171 DAT, a higher growth average rate $\left(0.56 \mathrm{~cm}\right.$ day $\left.^{-1}\right)$, however, it was also characterized by two different height increase cycles (up to 67 DAT and between 122 and 171 DAT), intermediated by a little vigorous growth period (between 67 and 122 DAT). According to Carvalho et al. (2013), the Jatropha plants show height increase that are considerably smaller in the reproductive stage compared to the vegetative stage, due to the mobilization of the bigger part of the synthetized photoassimilate for the fruits formation and filling. Carvalho et al. (2013) also mention that
KURIHARA, C. H. et al.

in hydric limitation conditions the growth rate reduction related to the crown height in the reproductive stage become more accurate due to the less production of photoassimilates.

The number of branches has presented linear adjustment in relation to the plants age (Figure 3), and in the data set that was obtained in all the evaluations, increases equivalent to 0.277 branches month ${ }^{-1}$ could be observed. However, the observation on the obtained data allows us to verify more expressive increases in four different periods (between 0 and 90 DAT: November/2008 and February/2009; between 375 and 459 DAT: December/2009 and February/2010; between 738 and 873 DAT: November/2010 and April/2011; and between 1,277 and 1,431 DAT: May to October/2012), normally associated to the most adequate conditions of temperature and hydric availability (Figure 1).

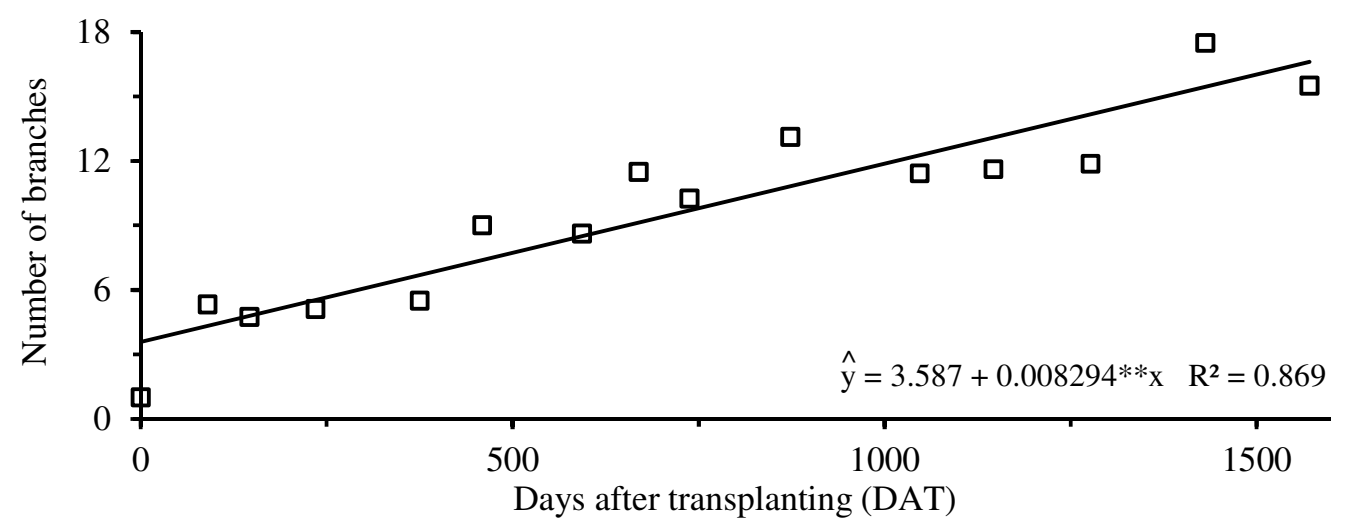

Figure 3. Number of branches in Jatropha plants due to the number of days after the seedlings planting in typical dystrophic Red Latosol, medium texture.

In Jatropha plants, the number of branches is a variable that is positive and highly correlated to the grains production, and this relation is even superior to the one observed for the height and the proportion of male and female flowers (RAO et al., 2008). According to Larcher (2004), this probably happens due to the fact that this plant's productive structures are located in the branches apical edge.

Based on the regression equation shown in the Figure 3, it was calculated that in the 1,571 DAT, the plants presented 16.6 branches, number that is considerably higher than the observed one by Silva (2011) in three years old plants (6.1) cultivated in Dystrophic Red Latosol, from Dourados-MS. However, Saturnino et al. (2005) emphasize that this variable can be influenced by several aspects such as: the seedling production time; the planting period; nutrients supply; presence of soil compaction or competition with the invader plants and the occurrence of hydric deficit or disease. The production of secondary branches can also be improved through trimming, and Saraiva et al. (2013) certified a nearly three times increase, six months after the trimming of the primary branches in a height of $80 \mathrm{~cm}$ from the soil.

The stem diameter (Figure 4), in a similar way of the observed one with the plants height, has also shown three growth cycles; however, the reduction in the improvement rate checked in the second and in the third cycle in relation to the first one has happened in a less pronounced way in relation to the observed one in that variable. Based on the equation of adjusted cubic regression and the calculus procedures mentioned before, it was estimated that the stem growth rate was 0.0196; 0.00859 and $0.0101 \mathrm{~cm} \mathrm{day}^{-1}$, respectively, in the first year (375 DAT), between 12 and 29 months (375 and 873 DAT) and between 29 and 52 months 
(873 and 1,571 DAT). In the last evaluation, it was verified a $20.5 \mathrm{~cm}$ diameter, according to Arruda et al. (2004) and Alves et al. (2008), who mentioned values close to $20 \mathrm{~cm}$ in adult plants. In contrast, in the State of Roraima, Smiderle and Kroetz (2009) have certified linear improvements in the Jatropha stem diameter, measured in the soil level, up to 24 months old, so having the maximum value of 35.9 $\mathrm{cm}$. On the other hand, Silva (2011) has observed average stem diameter of $12.7 \mathrm{~cm}$ in three years old plants that are involved with intercropping with different forage species and species for grains production.

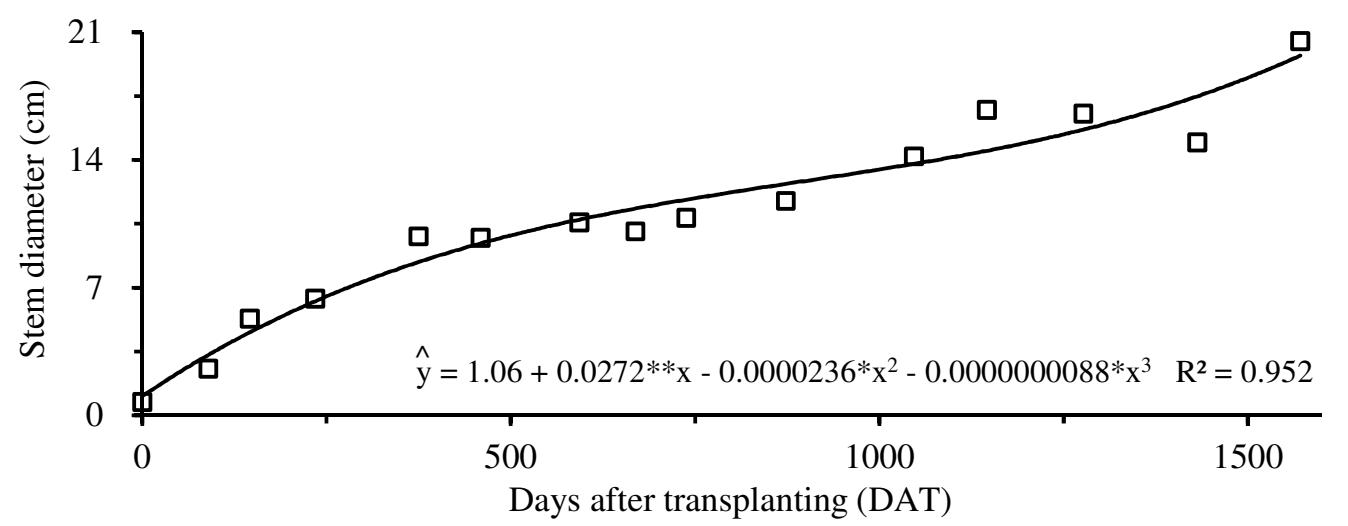

Figure 4. Stem diameter of Jatropha plants due to the number of days after the seedlings transplanting in typical dystrophic Red Latosol, medium texture.

In turn, the crown diameter (Figure 5) has shown intense growth until the $15^{\text {th }}$ month $(459$ DAT) and again from the $35^{\text {th }}$ month on $(1,047$ DAT), with the observation of a less biological activity period between these two periods. Based on the cubic model presented in Figure 5, improvement rates were estimated with $0.314 ; 0.108$ and 0.328 $\mathrm{cm}$ day $^{-1}$, respectively, until the $15^{\text {th }}$ month $(459$ DAT), between the $15^{\text {th }}$ and $35^{\text {th }}$ month (459 and 1,047 DAT) and between the $35^{\text {th }}$ to the $52^{\text {nd }}$ month (1,047 and 1,571 DAT). In the 1,571 DAT, the maximum value obtained for this variable was 409 $\mathrm{cm}$, which was $21.0 \%$ higher than the height evaluated in this date $(338 \mathrm{~cm})$. However, it has to be pointed that the relation between the crown diameter and the plants height is a very variable characteristic for the Jatropha, because of the high variability that exists in this still domesticating specie, whose available genetic material is still heterogeneous and segregating. According to Alves et al. (2008), this happens when the seminal propagation is done based on the fact that the specie shows high rate of cross pollination.

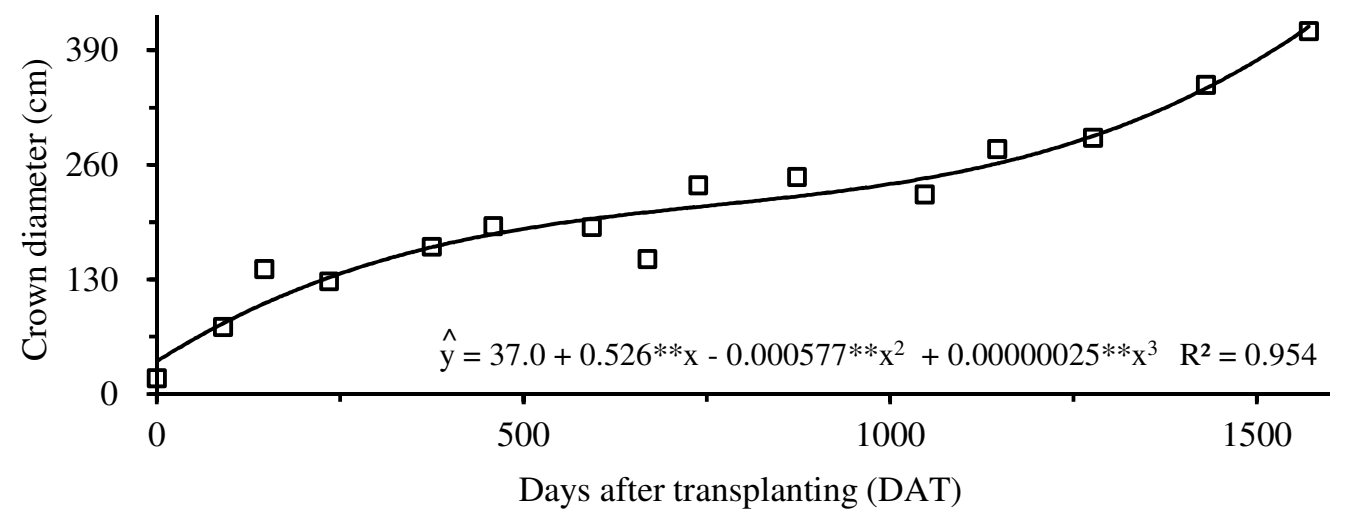

Figure 5. Crown diameter of Jatropha plants due to the number of days after the seedlings planting in typical dystrophic Red Latosol, medium texture.

It is emphasized that among the 15 evaluations that were done during the 1,571 DAT, the relation crown diameter/height has varied from 0.71 to 1.35 , with the average of 1.02 . This genetic variability is easily noticed in Jatropha commercial farming, where you can see dossals in several different shapes as expected just like the 
expectations on the differences due to the adopted spacing in the planting.

The phytomass production of crown dry matter (Figure 6) has presented quadratic improvements during the evaluated period, so from the adjusted regression equation on, by adopting the same calculus procedures that were used for the plants height, it was verified the different accumulation rates in three different periods. During the first eight months after the seedlings transplanting (235 DAT), little improvements were observed in this variable (average of $2.06 \mathrm{~g} \mathrm{day}^{-1}$ ). In the following periods which had the duration of 27 months (between 235 and 1,047 DAT) and 17 months (between 1,047 and 1,571 DAT), accumulation rates of dry matter phytomass considerably higher were estimated (5.15 and $9.08 \mathrm{~g}$ day $^{-1}$, respectively).

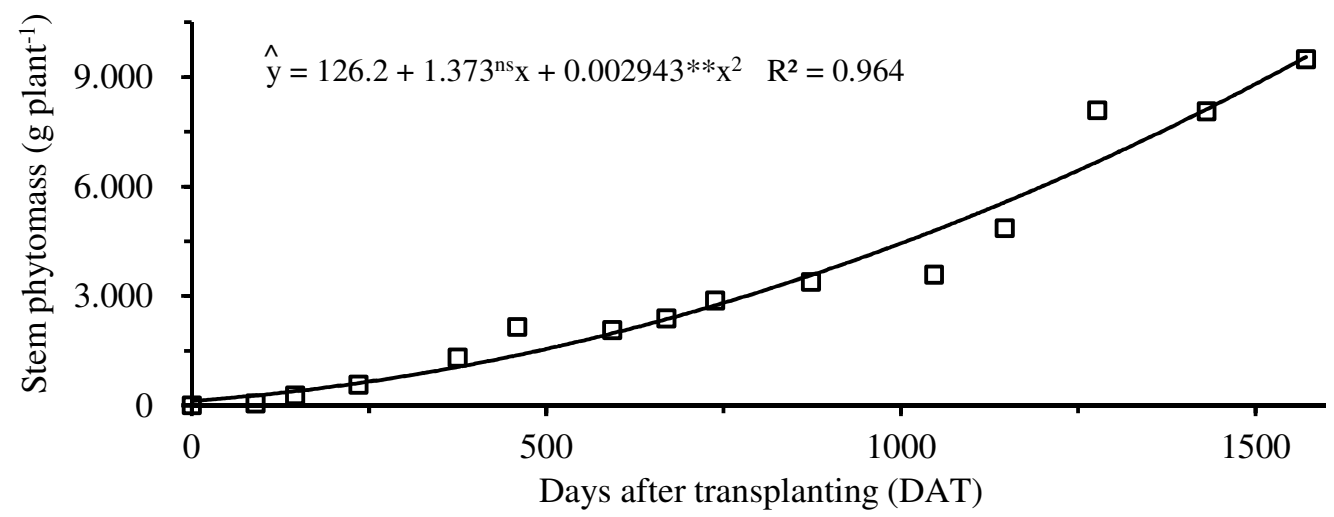

Figure 6. Stem dry phytomass of Jatropha plants due to the number of days after the seedlings planting in typical dystrophic Red Latosol, medium texture.

This result is probably related to the existence of an adjustment of potential model between the stem dry matter phytomass and the variables of plants height, crown and stem diameter and the number of branches, in Jatropha plants (Figure 7), where, initially, improvements in these variables result on small phytomass additions. However, when the plant reaches $126 \mathrm{~cm}$ high, around the 235 DAT, the stem phytomass linearly increases with these variables improvements. The crown dry matter phytomass production obtained in the 52 months of evaluation (1,571 DAT) was 9,547 g plant ${ }^{-1}$, corresponding to $11,934 \mathrm{~kg} \mathrm{ha}^{-1}$. It calls the attention the fact that the average of the 15 evaluations done in the 52 months period, the stem dry matter phytomass corresponded to only $23.0 \%$ of the fresh matter phytomass.
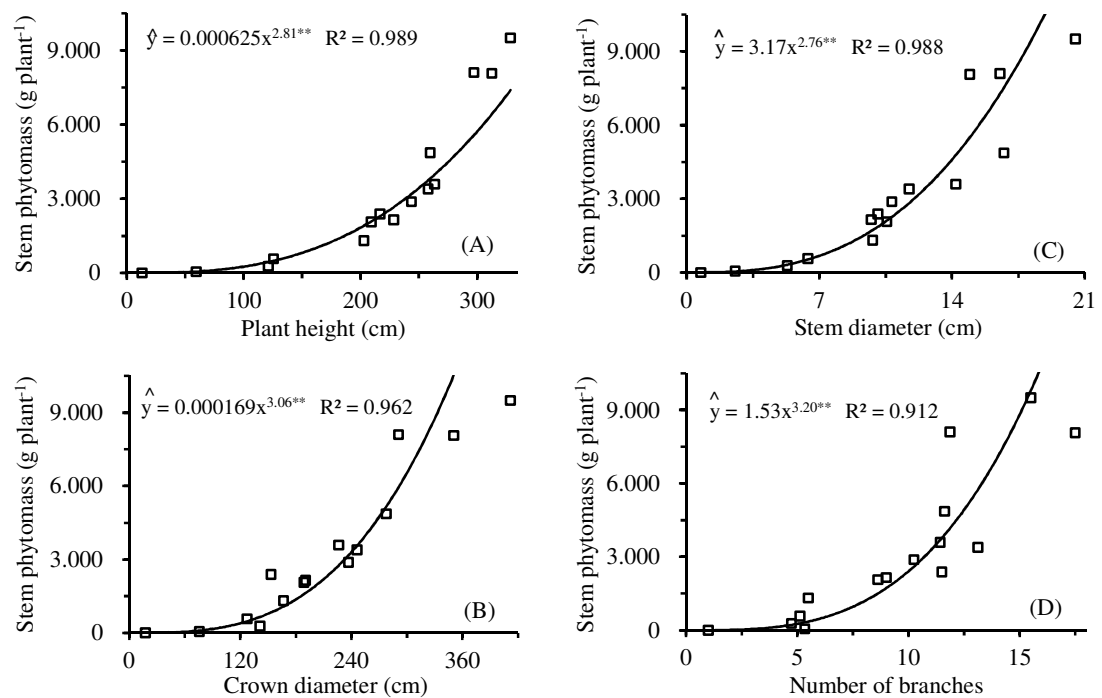

Figure 7. Stem dry phytomass of Jatropha plants due to the plants height (A), crown (B) and stem (C) diameter and number of branches (D) in typical dystrophic Red Latosol, medium texture. 
According to Saturnino et al. (2005), the high content of water in the crown is a characteristic of the specie and it is used by the plant during the critical periods of temperature and hydric availability. However, in this work, consistent differences in the relation dry phytomass/fresh phytomass were not found in the evaluations done during the period of fall/winter (0.233), in comparison to the ones done in the warmer and rainier period $(0.228)$

The production of dry matter phytomass of leaves was a variable influenced in more intensity during the evaluation period (Figure 8), due to the foliar abscission and senescence that naturally happens in the drier and/or colder periods, followed by the fast emission of new leaves when the climate conditions become favorable (ARRUDA et al., 2004; SATURNINO et al., 2005). Pronounced decreases in the dry phytomass accumulation have been observed in the evaluations done in September/2010 (669 DAT), April/2011 (873 DAT) and May/2012 (1,277 DAT). It must be emphasized that a decrease in the dry matter accumulation was also detected in March/2013 (1,571 DAT); however, this was associated with the occurrence of leaf senescence in the lower third of the canopy plants, between December and March, due to the photoassimilates drain, since the plants were in reproductive stage and there was the presence of inflorescences and fruits.

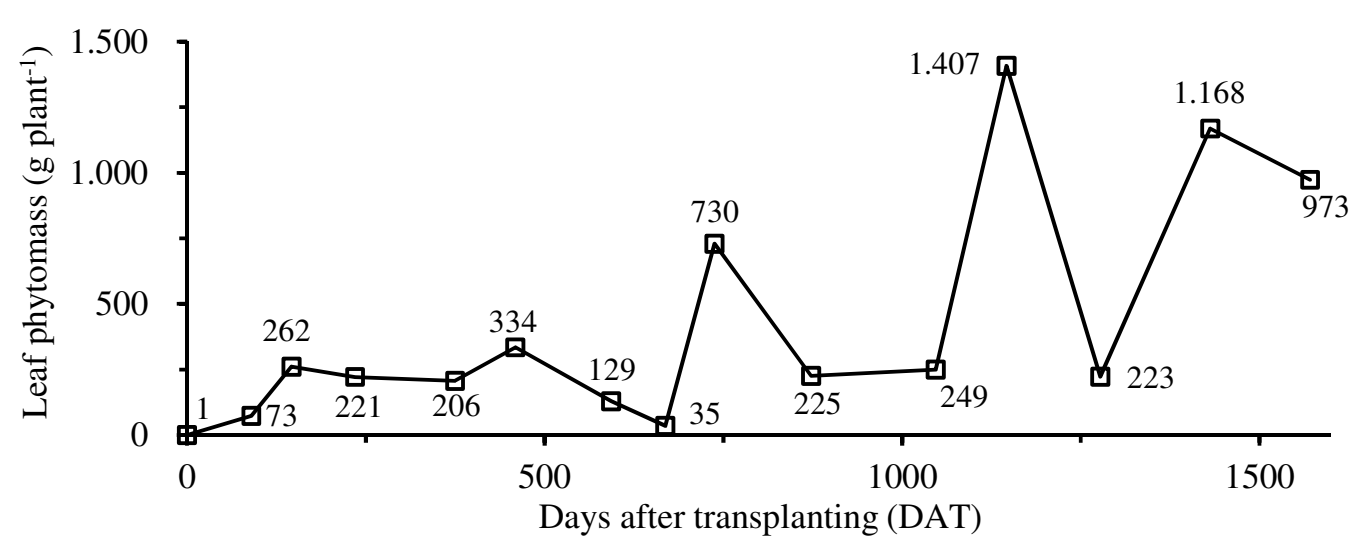

Figure 8. Dry phytomass of Jatropha plants leaves due to the number of days after the seedling transplanting in typical dystrophic Red Latosol, medium texture.

In the Figure 8, it is important to highlight the bigger quantity of dry matter phytomass of leaves that was registered in the 1,146 DAT $(1,407$ $\mathrm{g}$ plant $^{-1}$, corresponding to $\left.1,759 \mathrm{~kg} \mathrm{ha}^{-1}\right)$, and similarly to what was observed to the stem, the leaves also store considerable water content, whith relation dry phytomass/fresh phytomass of 0.235 . In greenhouse conditions, Pacheco et al. (2006) have observed, in five months old plants, that the relation between dry phytomass and fresh phytomass was even closer for both stem (0.131) and foliar limb (0.197).

\section{CONCLUSIONS}

The Jatropha plants growth, especially related to its height and stem and crown diameter, is more intense in the first twelve to fifteen months after the seedlings transplanting.
The stem diameter shows two growth cycles, between the $12^{\text {th }}$ and $15^{\text {th }}$ month and between the $35^{\text {th }}$ and the $52^{\text {nd }}$ month.

The crown dry matter accumulation considerably increases from the eighth month on, after the seedlings transplanting.

There is an intense foliar abscission and senescence in the Jatropha plants during the drier and colder periods of the year.

\section{ACKNOWLEDGMENTS}

The authors thank the State University of Mato Grosso do Sul - UEMS, for the opportunity to carry out the trial design in the University Unit of Cassilândia-MS. The authors also thank Embrapa, MCT/FINEP and PETROBRAS for the financial support to this research.

RESUMO: As plantas de pinhão-manso são caracterizadas pela rusticidade, com pouca exigência nutricional e hídrica. Por esta razão, têm sido utilizadas na recuperação de terras degradadas ou como cerca viva. Porém, em condições edafoclimáticas adequadas, pode-se tornar uma cultura alternativa para a produção de óleo diesel, por suas características 
de teor e qualidade industrial. Estudos sobre o crescimento e a marcha de acúmulo de fitomassa de parte aérea de plantas perenes subsidiam práticas de manejo da cultura, tais como a definição da população e do arranjo de plantas; também possibilita a estimativa da demanda e do potencial de reciclagem de nutrientes, o que contribui para o estabelecimento da quantidade e da época mais adequada para o fornecimento de adubos em cobertura. Trabalhos já publicados sobre avaliações do crescimento e do acúmulo de fitomassa têm abrangido um período de avaliação relativamente curto, algumas vezes em condições de casa de vegetação. Com o objetivo de avaliar a campo o crescimento e a marcha de acúmulo de fitomassa em plantas de pinhão-manso, conduziu-se um experimento em Cassilândia, MS, por um período de 52 meses. Adotou-se o delineamento experimental inteiramente ao acaso com quatro repetições e 15 tratamentos, correspondentes às épocas de avaliação. Verificou-se que o crescimento das plantas de pinhão-manso, principalmente em relação à sua altura e diâmetro de caule e de copa, é mais intenso nos primeiros doze a 15 meses após o transplantio das mudas. Para o diâmetro de copa, houve novo ciclo de crescimento, entre o $35^{\circ}$ e o $52^{\circ}$ mês, em taxa superior à observada no período inicial. O acúmulo de matéria seca de caule é relativamente pequeno até oito meses após o transplantio das mudas, aumentando consideravelmente a partir deste período. Há intensa senescência e abscisão foliar nas plantas, nos períodos mais secos e frios do ano.

PALAVRAS-CHAVE: Altura. Diâmetro de caule. Diâmetro de copa. Número de ramos.

\section{REFERENCES}

AlbuQUerQue, W. G. de; FREIRE, M. A. de O.; BELTRÃO, N. E. de M.; AZEVEDO, C. A. V. de. Avaliação do crescimento do pinhão manso em função do tempo, quando submetido a níveis de água e adubação nitrogenada. Revista de Biologia e Ciências da Terra, São Cristóvão, v. 9, n. 2, p. 68-73, 2009.

ALVES, J. M. A.; SOUSA, A. de A.; SILVA, S. R. G. da; LOPES, G. N.; SMIDERLE, O. J.; UCHÔA, S. C. P. Pinhão-manso: uma alternativa para a produção de biodiesel na agricultura familiar da Amazônia brasileira. Agro@mbiente On-line, Boa Vista, v. 2, n. 1, p. 57-68, 2008.

ARRUDA, F. P. de; BELTRÃO, N. E. de M.; ANDRADE, A. P. de; PEREIRA, W. E.; SEVERINO, L. S. Cultivo de pinhão manso (Jatropha curcas L.) como alternativa para o semi-árido nordestino. Revista Brasileira de Oleaginosas e Fibrosas, Campina Grande, v. 8, n. 1, p. 789-799, 2004.

ARRUDA, R. L.; QUEIROZ, P. A. de; COSTA, N. V. da; SARAIVA, A. de S.; ERASMO, E. A. L. Evaluation of the initial growth of Jatropha curcas L. under different doses of phosphorus applied to the base. Journal of Biotechnology and Biodiversity, Gurupi, v. 4, n. 4, p. 378-389, 2013.

CARVALHO, C. M. de; VIANA, T. V. de A.; MARINHO, A. B.; LIMA JÚNIOR, L. A. de; VALNIR JÚNIOR, M. Pinhão-manso: crescimento sob condições diferenciadas de irrigação e de adubação no semiárido nordestino. Revista Brasileira de Engenharia Agrícola e Ambiental, Campina Grande, v. 17, n. 5, p. 487496, 2013. https://doi.org/10.1590/S1415-43662013000500004

CEMTEC/MS. Banco de dados. Campo Grande, MS, 2017. Disponível em: <http://www.cemtec.ms.gov.br/?page_id=15>. Acesso em: 20 mar. 2017.

DALCHIAVON, F. C.; DALLACORT, R.; COLLETI, A. J.; MONTANARI, R.; PAZ-FERREIRO, J. Growth and productivity of purging nut (Jatropha curcas L.) crop grown on an Oxisol in Tangará da Serra (MT, Brasil). Cadernos do Laboratorio Xeolóxico de Laxe, Coruña, v. 37, p. 139-146, 2013.

FREIBERGER, M. B.; GUERRINI, I. A.; CASTOLDI, G.; PIVETTA, L. G. Adubação fosfatada no crescimento inicial e na nutrição de mudas de pinhão-manso. Revista Brasileira de Ciência do Solo, Viçosa, v. 38, n. 1, p. 232-239, 2014.

KURIHARA, C. H.; KIKUTI, H.; BINOTTI, F. F. da S.; SILVA, C. J. da. Nutrient accumulation, export and cycling in Jatropha curcas L. Revista Ceres, Viçosa, v. 3, n. 3, p. 355-360, 2016.

LARCHER, W. Ecofisiologia vegetal. São Carlos: Rima, 2004. 531 p. 
MEDEIROS, I. F. S.; LUCENA, D. S.; NUNES, A. R. V.; FERNANDES, L. G.; VIÉGAS, R. A. Crescimento e biomassa de plantas de pinhão-manso nutridas com composto orgânico. Revista Verde de Agroecologia e Desenvolvimento Sustentável, Pombal, v. 8, n. 1, p. 11-16, 2013.

OLIVEIRA, S. J. C.; BELTRÃO, N. E. de M. Crescimento do pinhão manso (Jatropha curcas) em função da poda e da adubação química. Revista Brasileira de Oleaginosas e Fibrosas, Campina Grande, v. 14, n. 1, p. 9$17,2010$.

PACHECO, D. D.; SATURNINO, H. M.; MENDES, L. D.; SOARES, F. R.; PAULA, T. O. M. de; PRATES, F. B. de S.; SOUZA, L. C. A. de. Produção de massa vegetal e composição mineral de plantas de pinhãomanso. In: CONGRESSO BRASILEIRO DE PLANTAS OLEAGINOSAS, ÓLEOS, GORDURAS E BIODIESEL, 3., 2006, Varginha. Anais..., Lavras: UFLA, 2006. p. 624-627.

PRATES, F. B, de S,; SAMPAIO, R. A.; SILVA, W. J. da; FERNANDES, L. A.; JUNIO, G. R. Z.;

SATURNINO, H. M. Crescimento e teores de macronutrientes em pinhão manso adubado com lodo de esgoto e silicato de cálcio e magnésio. Revista Caatinga, Mossoró, v. 24, n. 2, p. 101-112, 2011.

RAO, G. R.; KORWAR, G. R.; SHANKER, A. K.; RAMAKRISHNA, Y. S. Genetic associations, variability and diversity in seed characters growth, reproductive phenology and yield in Jatropha curcas (L.) accessions. Trees, v. 22, n. 5, p. 697-709, 2008. https://doi.org/10.1007/s00468-008-0229-4

SARAIVA, A. de S.; DORNELAS, D. F.; DORNELAS, B. F. M.; GONÇALVES, R. C.; ERASMO, E. A. L.; SARMENTO, R. de A.; NUNES, T. V. Growth and production of physic nut (Jatropha curcas L.) under phosphorus levels applied to the base. Journal of Biotechnology and Biodiversity, Gurupi, v. 4, n. 3, p. 240$248,2013$.

SATURNINO, H. M.; PACHECO, D. D.; KAKIDA, J.; TOMINAGA, N.; GONÇALVES, N. P. Cultura do pinhão-manso (Jatropha curcas L.). In: INFORME Agropecuário. Produção de oleaginosas para biodiesel. Belo Horizonte: EPAMIG, 2005. v. 26, n. 229, p. 44-78.

SILVA, A. N. da. Produção de pinhão manso (Jatropha curcas L.) em função da adubação, de níveis de água e da seletividade de herbicidas. 2010, 87f. Dissertação (Mestrado em Fitotecnia). Escola Superior de Agricultura "Luiz de Queiroz", Universidade de São Paulo, Piracicaba, 2010.

SILVA, J. A. N. da. Consórcio de pinhão-manso com espécies forrageiras e produtoras de grãos. 2011, 101f. Dissertação (Mestrado em Produção Vegetal). Universidade Federal da Grande Dourados, Dourados, 2011.

SIMÕES, W. L.; DRUMOND, M. A.; GUIMARÃES, M. J. M.; OLIVEIRA, A. R. de; FERREIRA, P. P. B.; Souza, M. A. de. Desenvolvimento inicial e respostas fisiológicas do pinhão manso (Jatropha curcas L.) a diferentes lâminas de irrigação e doses de nitrogênio. Revista Brasileira de Biociências, Porto Alegre, v. 12, n. 4, p. 188-195, 2014.

SMIDERLE, O. J.; KROETZ, V. J. Monitoramento de crescimento de pinhão manso em área de Cerrado em Roraima 2006 a 2008. In: CONGRESSO BRASILEIRO DE PESQUISA EM PINHÃO MANSO, 1., 2009, Brasília. Anais..., Brasília: MAPA/Embrapa Agroenergia/ABPPM, 2009. CD-ROM.

TOMINAGA, N.; KAKIDA, J.; YASUDA, E. K. Cultivo de pinhão-manso para produção de biodiesel. Viçosa: CPT, 2007. 220p. 